\title{
Glamorous Education: Main Features and Manifestations
}

\author{
Nikolaeva Evgeniya Mikhailovna ${ }^{1} \&$ Schelkunov Mikhail Dmitrievich ${ }^{1}$ \\ ${ }^{1}$ Kazan Federal University, Kazan, Russia \\ Correspondence: Schelkunov Mikhail Dmitrievich, Kremlevskaya Street, 18, 420008 Kazan, Russia. E-mail: \\ mikhail.schelkunov@rambler.ru
}

Received: August 5, 2014 Accepted: September 6, 2014 Online Published: October 29, 2014

doi:10.5539/ies.v7n11p97

URL: http://dx.doi.org/10.5539/ies.v7n11p97

\begin{abstract}
Being a powerful social trend glamour culture has significant effect on a high education that results in the phenomenon of glamorous education (glam-education). Prerequisites of this type of education are democratization of high school that introduces stereotypes of glam-culture in educational environment; commercialization of education that uses glamour as marketing instrument. The aim of this article is to reveal specifics of content, communicative, value, existential components of glam-education. In content dimension glam-education is characterized by reduction of fundamental component of education. Communicative practices of glam-education are filled with the spirit of hedonism, they articulate entertainment and recreational components of education as it is revealed in the article. The authors prove that in value dimension glam-education has the character of image benefit: the value of knowledge is replaced by its symbols (diploma, certificate). Glam-education is one of manifestations of existential crisis of personality in modern society because individual tries to compensate for his/(her) alienation from real qualifications and competencies by glam-image of his/(her) education.
\end{abstract}

Keywords: brand, glamour, education, consumption, symbol

\section{Introduction}

The term "glamour" is a polysemantic. According to its etymology, it still includes such original meanings, like magic, enchantment, bewitching power (to cast a glamour over-to charm, bewitch). Other values are "charm", "charisma", "fascination", and "attractiveness". In modern English a verb "to glamour up"-to embellish, praise-is used. In the mass consciousness the concept of "glamour" is associated mainly with the image of vie belle, delighting person with its brilliance, amazing its luxury, impressive extravagance and shocking incident.

However, it soon became evident that glamour is not just an aesthetic phenomenon or a kind of fashion. It has become a dominant type of culture-glamour culture (glam-culture) that manifests itself as a particular practice, psychology, ideology and lifestyle (Rudneva, 2010).

As a particular practice glam-culture, being generated by a global market society, is focused on the markets of entertainments, pleasures, show-performances, luxury and fashion. The main efforts of every glam-culture consumer are oriented on the acquisition of a set of the image benefits promised by the advertising of the glamorous production. Seeking a brilliant and attractive appearance (image), created on the basis of corresponding brands, is the main concern. A person is urged to show publicly eternal youth, sexuality, perfectness, sportiness, brightness and luxury (Rusakova, 2009).

With regards to its psychological aspect, glam-culture influences people by consumer temptation that constantly enforces the individual to design his/(her) own image by acquisition of goods belonging to famous brands. So every glam-oriented consumer dreams of becoming a brand himself, i.e., a self-brand (Rusakova, 2009).

In the ideological sense glam-culture is noted by absolute indifference to the values involving people in society, such as basic moral values (Ivanov, 2008, p. 4).

The main characteristics of a glamorous lifestyle are narcissism, hedonism, show chic, irony in "cool" style, eroticism, and image intellectualism, deficiency of authenticity, aestheticism, and rank thinking (thinking focused on top lists and nominations) (Ivanov, 2008, p. 4).

Maturing and escalation of glam-culture are promoted by three main factors. The first is consumer attitude of today person to life-consumerism (Baudrillard, 1998). Psychologically it results in reluctance of individual to 
personal efforts to active development of the world, tendency to "effort-free life" (Schelkunov \& Nikolaeva, 2010, p. 83). The second factor is symbolization (simulation) of life that erases difference between the reality and signs that define it. According to Baudrillard reality today is being replaced by simulacra that are self-referencing symbols of non-existent reality, "copies without an original". They replace real world by the set of impressive effects void in content dimension (Baudrillard, 1993). The third factor is mass society ("crowd") characterized by inclination to stereotypes and myth creation, social infantility, aesthetic pantophagy and moral relativism (Ortega, 1994).

Glam-culture as a powerful social trend has an essential impact on education. On the one hand, the present society widens access to higher education for vast categories of population, mainly for the "crowd." The latter brings glam-culture stereotypes into universities. On the other hand, as the educational system becomes a commercial enterprise, producing educational "services," the glam-culture proves to be one of the best marketing tools for these purposes. In the last regard, the glamorization of education correlates with its "McDonaldization." The latter means that the basic principles of educational management are similar to the principles of a fast food restaurant functioning (Ritzer, 1993), i.e. the process of education and its results should be calculated, predictable, controlled, effective and pleasant. Brightness and attractiveness, both with charm, together make glamour the irreplaceable promoter of McDonaldization in the educational field.

Education is a complex system combining various components: a content, communicative, value, existential, etc. Each of them today demonstrates the presence of glam-components. Aggregate of these components may be defined by the concept "glam-education".

\section{Methods}

In present research authors relied mainly on Bauman's concept of post-contemporaneity (Bauman, 2001, 2007), as well as on Baudrillard's (1998) and Miles' (1998) theory of consumer society.

Idea of the features of glamour as social and cultural phenomenon has been developed also under the effect of Gundle and Castelli's (2006), and Ivanov's (2008) works.

The authors' interpretation of the branding is based on the concept of M. Lindstrom, which can be positioned as a "brand philosophy" (Lindstrom, 2006).

Typical for sociological, pedagogical, cultural and philosophical studies methods (such as system, comparative historical, structural, functional, reflexive) were used in the research. Focus was made on the principle that activity of social institutions depends upon their social and cultural context. At the same time the authors were committed to interdisciplinary approach phenomenon and involved general scientific knowledge in research.

Results of sociological surveys of Pokrovski regarding global trends of modern university education (Pokrovski, 2005) and data of sociological surveys of students of Russian high educational institutions (Pautova, 2011) were used as empirical base. Long-term pedagogical experience of the authors' work in Kazan University was also taken into the account.

Moreover, an anonymous survey of teachers, 4th-5th year students, and postgraduate students (hereinafter - the students) of the Philosophical Faculty of Kazan Federal University during the 2014 spring semester was conducted. 64 teachers and 302 students participated in the survey.

The aim of the survey is a validation of authors' idea of glam-education.

Respondents were asked to answer three questions.

1) Do you recognize the influence of glam-culture on the higher education?

2) How do you assess the dynamics of the glam-trend in education for the last 3-4 years?

3) Which manifestations of glam education did you face during the education?

Questions \#1 and \#2 offered three variants of answers; the responder had to choose just one answer to each question. Question \#3 offered the respondent to answer at the same time in several (from 1 to 4 ) positions.

\section{Results}

1) In content dimension glam-trend in education weakens its fundamental component, unreasonably simplifies translated knowledge and skills. In such a way education reacts to unwillingness of glam-oriented students to pay maximum personal efforts for active studying of a subject, to their inclination to "effort-free" way of thinking. Education in the fields of natural science, mathematics, engineering sciences due to high intellectual capacity is less subjected to glamour affect than social and humanitarian education. Content base of the latter is glam-science that is oriented on simple, technological, conceptually superficial but "perfectly wrapped" 
solutions of social and humanitarian problems on base of routine ideas of management and marketing (Ivanov, 2007). Meanwhile experience of sciences development proves that simplicity and convenience are not always synonymous truth and correctness. Simplified education in the glamorous spirit is fraught with the risk of a decrease of the practical efficiency of the professional competences received at the university.

2) Communicative glam-educational practices are produced by the psychology of hedonism. Students' inability to realize hedonistic expectations from the content of educational products is compensated by getting pleasure of external form and conditions of educational process. This fact explains development of edutainment (combination of two English words "education" and "entertainment") i.e. educational technology based on the concept of learning by entertaining (Noddings, 2003). It manifests itself in such interactive forms as game, show, "media-theatre" etc. and gives rise to a special aesthetics of educational institution-festive aestheticism. It gives the impression of education as the "life holiday", and about the university as a place of pleasant pastime marked by reckless optimism, pleasure, fun, cult of the youth. This atmosphere is paradoxically often combined with cold-ironic and even cynical (in cool-style) attitude of students to the fundamental values of science, education and high culture. It is constructed in such a glam-formulas as "enjoy yourself!", "live playfully!", "take it easy!", "I deserve it", "image is all", etc.

3) In value dimension education under the impact of glam-culture gets the character of image benefit. It is not content of knowledge that is important for individual but external form of its representation (diploma, certificate). The value of knowledge is replaced by its symbols. The greater is the number of symbols and the greater is their prestige the more educated a person is in the opinion of the other people. Image-focused consumption causes brand-oriented consciousness that pushes individual to pursuit educational brands. This, for example, is education (rather stay) in the well-known university, learning the fashionable profession, coveted diploma, participation in an expensive educational program or famous training, familiarity with eminent teachers.

However, brand by definition is not more than a symbol of education that should be proved by real qualification and competence. But often prestigious university diploma covers mediocre knowledge of its owner, training with an eminent specialist reduces to obtaining the beautifully decorated certificate, and the dissertation is bought for money. In that case brand is transformed into a typical simulacrum that replaces those abilities that a person could not or did not want to develop in him/(her)self.

Imagism forms informational and image addiction of individual that means loss of capability to generate his $\backslash$ (her) own thoughts and images. Phenomenon of closed consciousness arises that is oriented on consumption of ready-made information. In practice it means forming of executive employee that is capable only to consume and lor reproduce knowledge (skills, qualification, and technology) that has been created by somebody, somewhere and sometime without personal attempt to transform it creatively.

4) Glam-education is one of indicators of existential crisis of individual in consumer society. If, according to E. Fromm, the person of the 20th century has resolved the vital dilemma "to be or to have?" mainly to the advantage of "to have", a person at the beginning of the 21 st century resolves another dilemma "to be or to seem?" mainly to the advantage of "to seem". Creating the illusion of an educated person, individual tries to compensate for his/(her) alienation from real knowledge, skills and qualification by glam-image of his/(her) erudition.

Subjecting reality to total sterilization and idealization in the mind, turning it into a world of glossy images and simulacra, glam-educated person ignores the contradictions inherent in the real life, castrates the meaning of such existential phenomena as love, life drama, suffering, death, etc. But it is known that contradiction is a root of any vitality. Thus external shine and nice "wrap" of glam-education mask the lack of original thoughts, productive imagination and genuine emotions.

Schematically, the main features of glam-education can be represented in the following table: 
Table 1. Glam education: main features and consequences

\begin{tabular}{|c|c|c|c|}
\hline \# & $\begin{array}{l}\text { Components of } \\
\text { education }\end{array}$ & Features of glam-education & Consequences of glam-education \\
\hline 1 & Content & $\begin{array}{l}\text { Defundamentalization and simplification } \\
\text { of the knowledge }\end{array}$ & $\begin{array}{l}\text { Decrease of the practical efficiency of the } \\
\text { professional competences received at the } \\
\text { university. }\end{array}$ \\
\hline 2 & Communicative & $\begin{array}{l}\text { Hedonistic, entertainment and recreational } \\
\text { practices, festive aestheticism }\end{array}$ & $\begin{array}{l}\text { Ironic and cynical attitude of students to } \\
\text { the fundamental values of science, } \\
\text { education and high culture. }\end{array}$ \\
\hline 3 & Value & Image benefit, simulation of education & $\begin{array}{l}\text { Executive employee, oriented on } \\
\text { consumption and/or reproducing of } \\
\text { ready-made knowledge }\end{array}$ \\
\hline 4 & Existential & $\begin{array}{l}\text { Ignoring the contradictions of the life, } \\
\text { sterilization and idealization of reality in } \\
\text { the mind }\end{array}$ & $\begin{array}{l}\text { Deficiency of original thoughts, } \\
\text { productive imagination, genuine emotions }\end{array}$ \\
\hline
\end{tabular}

Results of the survey of teachers and students are presented in the following tables.

Table 2. Influence of glam culture on the higher education

\begin{tabular}{llll}
\hline Question: Do you recognize the influence of glam culture on the higher education? \\
\cline { 2 - 4 } Respondents & \multicolumn{3}{c}{ Answers (in \%\%) } \\
\cline { 2 - 4 } & Yes & No & It is difficult to answer \\
\hline Teachers & 78,1 & 15,6 & 6,3 \\
Students & 58,9 & 23,5 & 17,6 \\
\hline
\end{tabular}

Table 3. Dynamics of glam-trend in education for the last 3-4 years

\begin{tabular}{lccc}
\hline \multicolumn{3}{l}{ Question: How do you assess the dynamics of the glam trend in education for the last 3-4 years? } \\
\hline \multirow{3}{*}{ Respondents } & Becomes stronger & Goes down & Remains unchanged \\
\cline { 2 - 4 } & 82,8 & 3,2 & 14,0 \\
\hline Teachers & 54,6 & 18,6 & 26,8 \\
Students & &
\end{tabular}

Table 4. The most expressive components glam education

\begin{tabular}{lcccc}
\hline \multicolumn{4}{l}{ Question: Which manifestations of glam education did you face during the education? } \\
\hline \multirow{2}{*}{ Respondents } & Content & Communicative & Value & Existential \\
\hline Teachers & 54,7 & 87,5 & 65,6 & 54,7 \\
Students & 34,1 & 58,3 & 67,9 & 36,1 \\
\hline
\end{tabular}

\section{Discussion}

The authors agree with Gundle (2008) and Postman (2013), who connect the expansion of glamour mainly with total aestheticization of social and individual human existence. However, in contrast to these colleagues, the authors believe that consumerism as the basic principle of the life of "mass" person has played no less important role in causing the glam-culture.

The authors acknowledge the fruitfulness of Hebdige's approach that explores glamour in the discourse of 
lifestyle. Style is considered by this author as cultural phenomenon and serves as an instrument for description of everyday person's activity. In this context, the style is a way for motivation of human behavior (Hebdige, 2005). At the same time, the authors believe that no less fruitful is a sociological interpretation of the lifestyle as a tool of glam-phenomena research.

Klein investigates glamour as a variant of lifestyle that is aimed at statuses (real and illusive). Very frequently this style is funded by brands-trademarks, associated in mass consciousness with images, values, symbols. Klein considers that branding, as a marker of glamour culture, swallows up individuality of the modern person (Klein, 2001). In the development of Klein's ideas the authors demonstrate the manifestations of branding in education and discover their illusory nature. In this respect, the authors detail the idea of Zizek, who pointed out simulative character of life of modern society and noted that final truth of capitalistic utilitarianism is dematerialization of real life and turning it into illusive show, into appearance of life (Zizek, 2002, p. 22).

Brown notes that glamour is "cold and indifferent dead", "is based on the abstraction", "values smoothly polished surface", but at the same time has special, attracting and absorbing force (Brown, 2009, pp. 98-99). The authors find this paradox in a glamorous education, indicating that its "sterile" idealness and beautiful "packaging" turns out in emasculating intellectual, emotional and volitional resources of the students.

Ivanov presented the theory of "glam-capitalism" that is super new version of capitalism where glamour became essential base of each activity. It includes the very rationality of modern capitalism, sets the shape of perception and gives meaning to any phenomena, funds the cultural, economic, technological, political logic of the consumer society. In this regard glamour produces numerous glam-phenomena: glam-consumption, glam-democracy, glam-science, glam-culture (Ivanov, 2008). The authors not without reason believe that they obtained a pioneer result: identified and described a new product of glam-culture-a phenomenon of glam-education.

Edutainment has been studied by a number of specialists (for example, Singhal et al., 2003) mainly from instrumental and technological points of view and in positive dimension as technology of education that is used in educational institutions, museums, entertainment centers, mass-media. However, the authors take a critical stance on the effectiveness of the edutainment, considering it mainly as possibility, according to Resnick, of holding "sweet" sessions with entertainment component instead of a serious work in the context of studied subject (Resnick, 2004). Highlighted by the authors "effort-free" character of glam-education is confirmed by Domeova and Jindrova. They marked the increase in the number of students different in unethical behavior, who try to reach the best results without own intensive and regular work, to get the graduation with minimum effort (Domeova \& Jindrova, 2013).

Results of the survey listed in the Tables $2-4$, convincingly confirm the recognition of glam-education and its main characteristics both from the educational community, and by the students.

\section{Conclusion}

Authors of the article have limited themselves to analysis of content, communicative, value and existential components of glam-education. Such components of glam-education as emotional, aesthetical, didactic, organizational, and technological remained beyond the scope of research. This is the limitation of undertaken research.

The subject of further research is a following problem: how to combine traditional (classical) base of high education with edutainment technologies, preserving of component that forms universal human capabilities in conditions of focused professional education.

The next problem for research concerns perspectives of glamour's expansion in education: whether glam-trend in high school is temporary phenomenon or sustainable long-term trend? To answer this question it is necessary to correlate research with analysis of social, economical and cultural contexts of high education.

Revealing of alternatives to glam-education may become especially pressing in case of further escalation of glam-trends. It will be also important to define people interested in these alternatives and in their value for society.

Results of research may be used in post-graduate training for university teachers, in methodological sphere and innovative technologies in high school, for organization of practical training, in compiling control and measurement materials (tests) as well as in working out development strategy of university education. 


\section{Acknowledgements}

This work was funded by the subsidy allocated to Kazan Federal University for the state assignment in the sphere of scientific activities.

\section{References}

Baudrillard, J. (1993). Symbolic Exchange and Death (p. 250). London: Sage Publications.

Baudrillard, J. (1998). The Consumer Society: Myths and Structures (p. 224). Sage Publications.

Bauman, Z. (2001). The Individualized Society (p. 252). Cambridge: Polity.

Bauman, Z. (2007). Consuming Life (p. 160). Cambridge: Polity.

Brown, J. (2009). Glamour in six dimensions: Modernism and the Radiance of form (p. 216). N.Y.: Cornell University Press.

Domeova, L., \& Jindrova, A. (2013). Unethical Behavior of the Students of the Czech University of Life Sciences. International Education Studies, 6(11), 77-85. http://dx.doi.org/10.5539/ies.v6n11p77

Gundle, S. (2008). Glamour: A History (p. 496). N.Y.: Oxford University Press.

Gundle, S., \& Castelli, C. T. (2006). The Glamour System (p. 224). N.Y.: Palgrave Macmillan.

Hebdige, D. (2005). Subculture: The Meaning of Style (New Accents) (p. 208). Routledge.

Ivanov, D. V. (2007). Glam-capitalism and social sciences. The journal of sociology and social anthropology, 2, 69-70.

Ivanov, D. V. (2008). Glam-capitalism (p. 176). St.-Petersburg: Petersburg Oriental Studies.

Klein, N. (2001). No logo: Taking Aim at the Brand Bullies (p. 490). Picador, USA.

Lindstrom, M. (2006). Brand sense (p. 237). Published by Kogan Page.

Miles, S. (1998). Consumerism as a way of life (p. 174). Sage Publications.

Noddings, N. (2003). Happiness and Education (p. 308). Cambridge, UK: Cambridge University Press.

Ortega, G. J. (1994). The Revolt of the Masses (p. 192). Norton \& Company.

Pautova, L. (2014). Generation of XXI century: An attempt of sociological survey. Retrieved from http://www.bd.fom.ru/pdf/prezzentria2.pdf

Pokrovski, N. E. (2005). Side product of globalization: Universities are faced dramatic changes. Social sciences and contemporaneity, 4, 148-154.

Postman, N. (2013). Amusing Ourselves to Death. Retrieved from http://www.mafhom.files.wordpress.com/ 2013/11/amusing-ourselves-to-death.pdf

Resnick, M. (2004). Edutainment? No thanks. I prefer playful learning. Associatzione Civita, 1(1), 2-4.

Ritzer, G. (1993). The McDonaldization of Society (p. 302). Thousand Oaks, Calif.

Rudneva, D. A. (2010). Glamour as phenomenon of culture of post-industrial society: Research method. Ural State University Gerald, 2(76).

Rusakova, O. F. (2014). Global glam-culture discource. Retrieved from http://www.madipi.ru/index.php?option $=$ com_content $\&$ view $=$ category\&layout $\mathrm{t}=$ blog $\& \mathrm{id}=75 \&$ Itemid $=64$

Schelkunov, M. D., \& Nikolaeva, E. M. (2010). Education in XXI century: Faced to new challenges (p. 156). Kazan: Kazan State University.

Singhal, A., Cody, M. J., Rogers, E. M., \& Sabido, M. (2003). Entertainment-Education and Social Change: History, Research, and Practice. Taylor \& Francis.

Zizek, S. (2013). Welcome to the Desert of the Real: Five Essays on September 11 and Related Dates (p. 160). Verso Books.

\section{Copyrights}

Copyright for this article is retained by the author(s), with first publication rights granted to the journal.

This is an open-access article distributed under the terms and conditions of the Creative Commons Attribution license (http://creativecommons.org/licenses/by/3.0/). 